\title{
Evaluation of nutmeg (Myristica fragrans Houtt) as active component during storage of bovine loins
}

\author{
Evaluación de nuez moscada (Myristica fragrans Houtt) como componente activo durante el \\ almacenamiento de lomos de bovino
}

\section{Yessica Galeano L. ${ }^{1}$; Olga Torres V. ; Ángela García S. ${ }^{3}$}

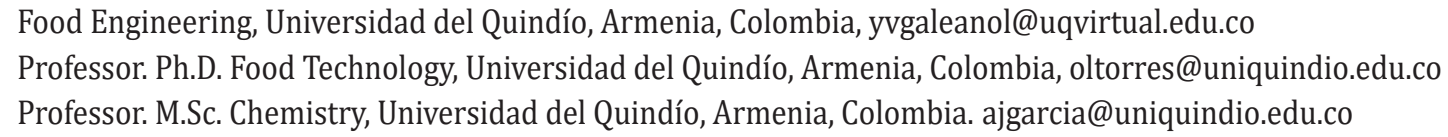

Cite: Galeano, Y., Torres, 0. \& García, A. (2018). Evaluation of nutmeg (Myristica fragrans Houtt) as active component during storage of bovine loins. Rev. Cienc. Agr. 35(1):48-57. doi: http://dx.doi.org/10.22267/ rcia.183501.82.

Received: June $192017 . \quad$ Accepted: October 302017.

\begin{abstract}
Meat products are considered highly perishable foods because of their physical, chemical and biological characteristics. Different compounds can be combined to produce active films with greater functionality, which can provide effective protection to food during storage. In this research, active films formulated with polyvinyl alcohol, gelatin, and different oleoresin concentrations of nutmeg (Myristica fragrans Houtt) were made by using the casting methodology, a process by which a solution is poured into a mold. Bovine loins (Longissimus dorsi) were coated with the active films formulated, stored at $4{ }^{\circ} \mathrm{C}$, performing physicochemical characterization for $1,3,6$ and 10 days. The results obtained indicate a decrease in $\mathrm{pH}$, humidity percentage, peroxide value (POVs), total volatile nitrogen bases (TVB-N) and greater conservation of the $\mathrm{a}^{*}$ parameter (coordinate where $+a$ indicates red, $-\mathrm{a}$ indicates green) in loins covered with active films during storage time. Thus, the active films formulated could be used in the meat industry to extend the shelf life of bovine loins.
\end{abstract}

Keywords: Active films, bases, color, peroxide value, volatile nitrogen. 


\section{RESUMEN}

Los productos cárnicos son considerados alimentos altamente perecederos debido a sus características físicas, químicas y biológicas. Diferentes compuestos se pueden combinar para la obtención de películas activas con una mayor funcionalidad, que puedan brindar una protección eficaz a los alimentos durante el almacenamiento. En la presente investigación se elaboraron películas activas, formuladas con polivinil alcohol, gelatina y diferentes concentraciones de oleorresina de nuez moscada (Myristica fragrans Houtt), empleando la metodología de casting, proceso mediante el cual una solución es vertida en un molde. Lomos de bovino (Longissimus dorsi) fueron cubiertos con las películas activas formuladas, almacenados a $4^{\circ} \mathrm{C}$, realizando una caracterización fisicoquímica durante 1, 3, 6 y 10 días. Los resultados obtenidos indicaron una disminución en el pH, porcentaje de humedad, índice de peróxido (POVs), bases volátiles nitrogenadas totales (TVB-N) y una mayor conservación del parámetro a* (coordenada donde +a indica rojo, -a indica verde) en los lomos cubiertos con las películas activas, durante el tiempo de almacenamiento. Por lo tanto, las películas activas formuladas podrían ser utilizadas en la industria cárnica para prolongar la vida útil de los lomos de bovino.

Palabras clave: Bases volátiles nitrogenadas, color, índice de peróxidos, películas activas.

\section{INTRODUCTION}

Storage time of fresh meat could be extended by using coating agents that delay normal decomposition processes, without modifying the chemical and sensory attributes that characterize it (Antoniewski and Barringer, 2010). Fresh meat and meat conserved under refrigeration conditions $\left(4-5^{\circ} \mathrm{C}\right)$, during its distribution and consumption, has a limited shelf life between 5 and 6 days due to post mortem autolytic changes from the transformation of the muscle into meat protein and phenomena of lipid oxidation (Zhang et al., 2013). Some studies have demonstrated that shelf life and meat quality can be improved by natural antioxidants added during stages prior to slaughter and post-slaughter (Velasco and Williams, 2011). Antioxidants are compounds that inhibit or delay the oxidation of other molecules or the propagation of oxidizing chain reactions. In meats, lipid oxidation produces rancidity, bad flavor, and unwanted chemical reactions. Recent studies have shown that the active substances contained in nutmeg oleoresins (NO) can act as antioxidants in lipid oxidation in meat (Umaraw and Verna, 2017).
Polymer films can incorporate active substances in their formulation, which turn them into active containers or films for foods. Incorporation of antioxidants and antimicrobials into coating films is carried out to extend the shelf life of foods, delaying lipid oxidation, growth of fungi, yeasts, and bacteria during storage and distribution (Sánchez et al., 2014).

Active films create a gas barrier, reducing permeability and molecule exchange with the environment, thus, avoiding food deterioration; these are characterized by their capacity to act together to improve quality, prolong shelf life, and improve the storage conditions of foods, thus, diminishing the environmental impact produced by plastic materials and increasing sustainability in food industries (Peelman et al., 2013).

Although several conservation methodologies have been studied, currently, prolonging the shelf life of meat continues being a big technological challenge, given the high losses by this costly and nutritional product that reach between 25 and $33 \%$ of the total production costs (FA0, 2014) and up to $40 \%$ according to that reported by Lorenzo et al., (2014). Hence, the aim of this research was to evaluate the effect of active films with nutmeg on the chemical and microbiological characteristics of bovine loins during storage at $4^{\circ} \mathrm{C}$. 


\section{MATERIALS AND METHODS}

This research was conducted in the Food Laboratory at the Science Interdisciplinary Institute in Universidad del Quindío. To produce the active films, this work followed the methodology described by Figueroa-López et al., (2016a). Initially, an aqueous suspension at $3 \% \mathrm{p} / \mathrm{p}$ of type B gelatin polymer (Bloom 220 - 240) and distilled water at $60^{\circ} \mathrm{C}$ was homogenized, then the gelatin was added and kept under constant stirring for 30 min at $600 \mathrm{rpm}$. At the same time, an aqueous suspension was prepared with $5 \%$ of polyvinyl alcohol (PVA) (Sigma), which was homogenized during $30 \mathrm{~min}$ at $90^{\circ} \mathrm{C}$. Additionally, a sorbitol solution (99\% Sigma-Aldrich) was prepared at $15 \%$ heating at $35^{\circ} \mathrm{C}$ for $15 \mathrm{~min}$. Upon obtaining the solutions, nutmeg oleoresin (NO) (TECNAS, Colombia) was added as active component in concentrations of $0.5,1.0$, and $1.5 \%$, according to the Figueroa et al., (2016b) method. Finally, all the components were mixed for $15 \mathrm{~min}$, distributed over a plastic mold, and dried in an air-circulation stove at $45^{\circ} \mathrm{C}$, during $6 \mathrm{~h}$, until obtaining the active films with nutmeg oleoresin (AFNO). As control, a control film (CF) was formulated without adding NO.

To evaluate the effect of the AFNO, these films were used to cover samples of bovine loin cubes (Longissimus dorsi) of $2 \times 2 \times 2 \mathrm{~cm}$ with a weight of $20 \mathrm{~g}$ approximately, cut in parallel direction to the muscle fibers, with one day post mortem and obtained from the Frigocafé slaughter center in the Armenia city (Quindío), which has INVIMA certification for the slaughter of bovines. As control, a loin was covered with a CF. Finally, the loins were stored at $4^{\circ} \mathrm{C}$ for their subsequent physical-chemical analysis during $1,3,6$, and 10 days. The analyses were performed in triplicate and by previously removing the film.

Physical-chemical analysis. The $\mathrm{pH}$ measurements were carried out through a Crison $\mathrm{PH} 25^{\circledR}$ portable awl potentiometer (Crison Instruments
S.A., Spain) and moisture content $\left(\mathrm{x}^{\mathrm{w}} \mathrm{g} / \mathrm{g}\right)$ was determined by desiccation of the samples in a stove at $100^{\circ} \mathrm{C}$ until the samples reached constant weight (ISO, 1997).

Color analysis. To determine the different color parameters in the bovine loin samples, a Minolta CM-2002R spectrophotometer (Minolta Camera Co., Osaka, Japan) was used, using illuminant D65 and a $10^{\circ}$ standard observer (UNE 40-080, 1984). Color determination and expression was conducted based on the CIELAB coordinates and the reflectance values (CIE, 1976). The luminosity $\left(L^{*}\right)$, red-green $\left(a^{*}\right)$, yellow-blue $\left(b^{*}\right)$ parameters were obtained directly from the equipment.

Peroxide value (POVs). Upon finishing the days of storage, the bovine loin samples were analyzed. As target, a sample stored and covered with a CF was used. Lipids were extracted from the loin samples with a mixture of water, methanol, and chloroform (30: 50: 100, v/v). The peroxide values, of the extracts, were measured by the AOAC Method (Horwitz, 2005). The POVs was calculated through the equation (1).

$$
\operatorname{POV}\left(\frac{m e q}{k g}\right)=(S-B) * F * \frac{m o l}{L(N)} * \frac{1000}{W}
$$

Where $S, B, F, \mathrm{~mol} / L(N)$, and $W$ indicate the volume spent on the titration of the sample, the amount of volume spent on the titration of the target, normality of the $\mathrm{Na}_{2} \mathrm{~S}_{2} \mathrm{O}_{3}(0.01 \mathrm{~mol}$ equivalent/L), and the sample weight $(\mathrm{g})$, in their order.

Total volatile basic nitrogen (TVB-N). The total content of volatile basic nitrogen in the bovine loin samples stored with AFNO was conducted through distillation, which is the method described by Botta et al., (1984). The amount of TVB-N was calculated through equation (2). The result indicated for each sample was the mean value of both measurements: 


$$
T V B-N\left(\frac{m g}{100 g}\right)=\frac{\left(v_{1}-v_{2}\right) * c * 14}{m * \frac{5}{100}} * 100
$$

Where $v_{1}$ is the titration volume for the sample analyzed $(\mathrm{ml}), \mathrm{v}_{2}$ is the titration volume in the target $(\mathrm{ml}), c$ is the concentration of $\mathrm{HCl}\left(\mathrm{mol} \mathrm{L}^{-1}\right)$ and $m$ is the loin sample weight (g).

Microbiological analysis. The microbiological analysis evaluated loin samples with 1, 3, 6, and 10 days of storage, applying the following methodology: Staphylococcus aureus positive coagulase NTC 4779 (ICONTEC, 2007), sulfite-reducing Clostridium spores NTC 4834 (ICONTEC, 2000), detection of Salmonella NTC 4574 (ICONTEC, 2007), respectively. For Coliform count and detection of Escherichia coli was conducted through the procedure described in the NTC 4458 standard (ICONTEC, 2007).

Statistical analysis. A four-factor analysis of variance (ANOVA) was carried out (nutmeg concentration) with four replicates (days of storage) with $95 \%$ CI ( $\mathrm{p} \leq 0.05)$ where the AFNO and storage time of the loin samples were the input factors and the response variables were those obtained from the $\mathrm{pH}$, humidity, color ( $\mathrm{L}^{*}, \mathrm{a}^{*}$, and $\mathrm{b}^{*}$ ) POVs, and TVB$\mathrm{N}$ analyses. All the experiments were performed in triplicate and were analyzed by using the Statgraphics Centurion XVII statistical package.

\section{RESULTS AND DISCUSSION}

The $\mathrm{pH}$ of samples covered with AFNO had a significant decrease $(\mathrm{p}<0.05)$ during the days of storage $1,3,6$, and 10 , being more accentuated in the CF, as observed in Figure 1. This behavior may be caused by to dissociations of organic acids, like lactic acid and acetic acid in the muscle tissue of the loins and to the loss of fluid from the meat tissue that causes increased concentration of the solutes and produces decreased pH (Wei et al., 2017).

Significant differences ( $p<0.05)$ were obtained between the final $\mathrm{pH}$ of the loin samples and the film used to cover them during storage. This indicates that the AFNO can maintain optimal $\mathrm{pH}$ values in the loins during storage.

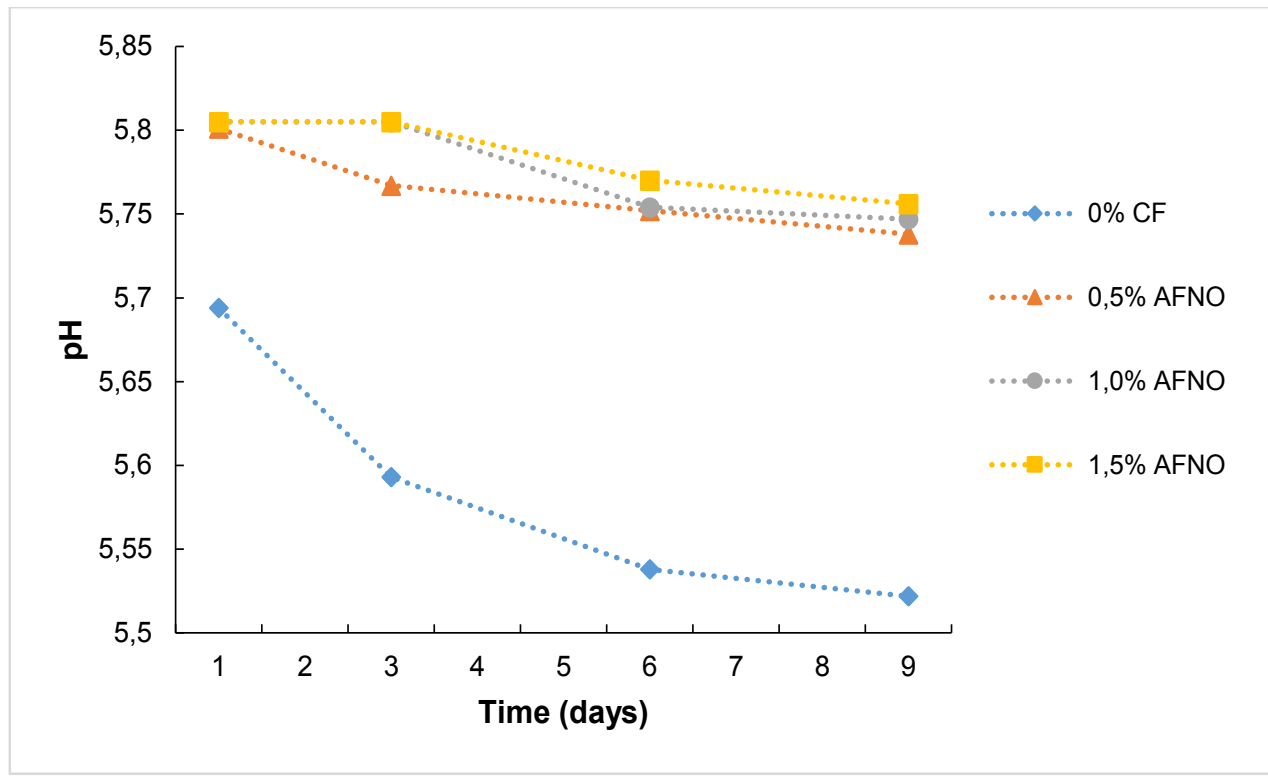

$\mathrm{CF}=$ control film; $\mathrm{AFNO}=$ Active film with nutmeg oleoresins

Figure 1. pH values against storage time in bovine loins covered with active films with nutmeg oleoresins (AFNO). 
These results agree with Šojić et al., (2015), who studied the effect the nutmeg essential oil on the stability of cooked sausage during refrigerated storage, obtaining a decrease in $\mathrm{pH}$ during storage; likewise, the sausages had a lower $\mathrm{pH}$ value, but significantly higher $(p<0.05)$ compared to sausages used as control.

Loin samples covered with AFNO had a significant decrease in moisture content $(\mathrm{p}<0.05)$ with the increase of storage time, being lower than the decrease presented in the CF, as noted in Figure 2. The behavior presented in the loin samples with AFNO was due to the NO which is an oily liquid that acts as a protection barrier, that covers the loin surface, avoids moisture loss during storage, and reduces water migration. Water loss is one of the big problems to processors because it affects the meat weight (Antoniewski and Barringer, 2010). The results agree with Antoniewski et al., (2007), who found that coating of $20 \%$ gelatin reduced the purge in beef, pork, and poultry for 14 days under refrigeration.

Color in meat is the principal attribute to determine its freshness. Therefore, it becomes one of the main concerns for processors who seek methods to maintain it. Table 1 shows the results for the CIELAB coordinates of bovine loin samples covered with AFNO during storage at $4^{\circ} \mathrm{C}$. Redness ( $a^{*}$ value) of the samples with different NO concentrations had significant differences ( $p$ $<0.05$ ) against samples covered with the control film (CF), while the yellow ( $b^{*}$ value) had no significant differences. These results are attributed to the relationship among the color stability, the lipid oxidation and natural pigments (Mancini and Hunt, 2005). Results for luminosity ( $\left.\mathrm{L}^{*}\right)$ in the loins covered with the control film presented an increase from 32.703 to 41.093 during storage time, as consequence of the reflection of scattered light due to oxidized lipids (Zaritzky, 2012).

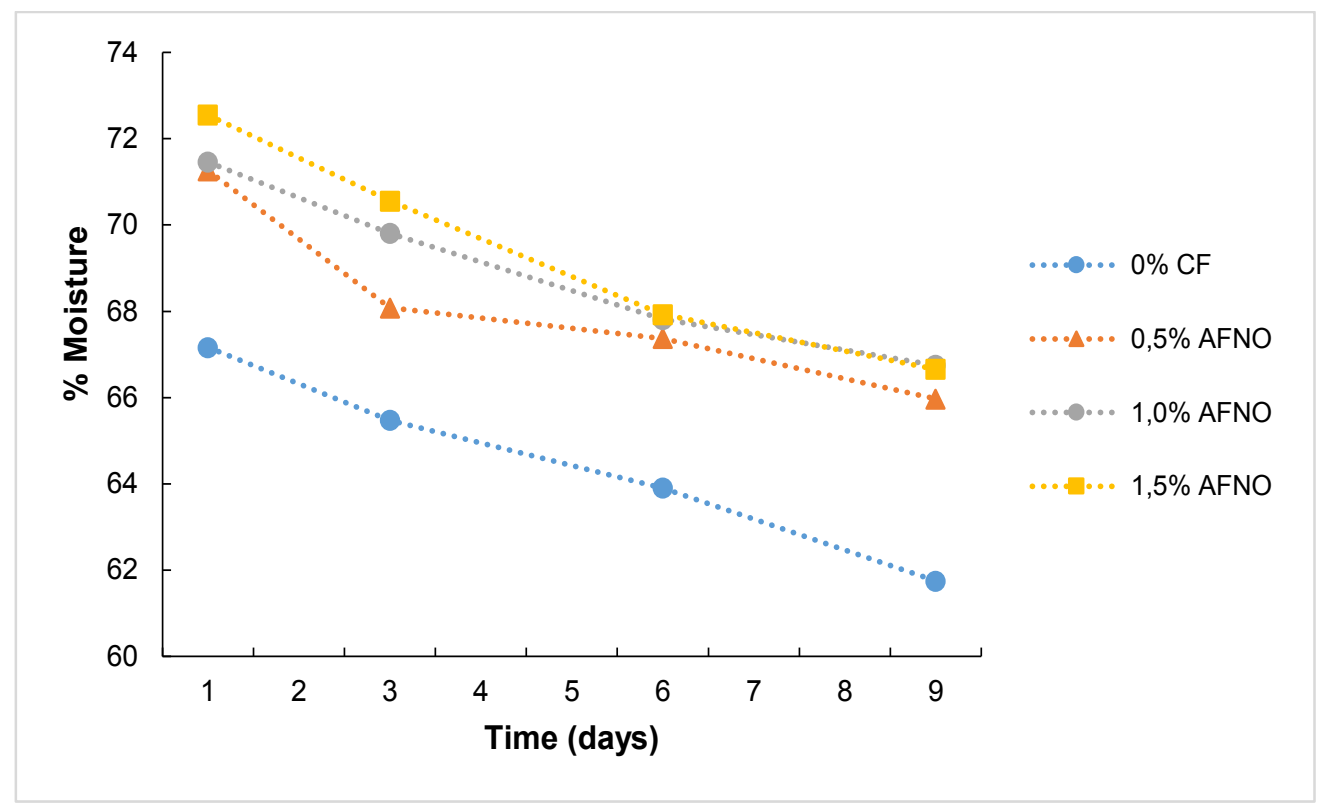

$\mathrm{CF}=$ control film; $\mathrm{AFNO}=$ Active film with nutmeg oleoresins

Figure 2. Moisture values against storage time in bovine loins covered with active films with nutmeg oleoresins (AFNO). 
Table 1. CIELAB coordinates of bovine loin samples

\begin{tabular}{|c|c|c|c|}
\hline Sample & $\mathbf{L}^{*}$ & $\mathrm{a}^{*}$ & $\mathbf{b}^{*}$ \\
\hline \multicolumn{4}{|c|}{ One day of storage } \\
\hline $0 \% \mathrm{NO}$ & $35.703 \pm 0.128$ & $9.828 \pm 0.016$ & $4.517 \pm 0.013$ \\
\hline $0.5 \%$ AFNO & $37.720 \pm 0.041$ & $11.787 \pm 0.535$ & $6.695 \pm 0.069$ \\
\hline $1.0 \%$ AFNO & $37.638 \pm 0.132$ & $10.576 \pm 0.06$ & $5.309 \pm 0.035$ \\
\hline 1.5 AFNO & $36.002 \pm 0.021$ & $12.776 \pm 0.029$ & $7.557 \pm 0.039$ \\
\hline \multicolumn{4}{|c|}{ Three days of storage } \\
\hline $0 \%$ NO & $33.732 \pm 0.0052$ & $8.741 \pm 0.052$ & $4.658 \pm 0.029$ \\
\hline $0.5 \%$ AFNO & $36.424 \pm 0.024$ & $16.913 \pm 0.140$ & $10.11 \pm 0.031$ \\
\hline $1.0 \%$ AFNO & $36.479 \pm 0.092$ & $14.253 \pm 0.026$ & $7.594 \pm 0.035$ \\
\hline 1.5 AFNO & $35.953 \pm 0.004$ & $15.357 \pm 0.025$ & $9.372 \pm 0.062$ \\
\hline \multicolumn{4}{|c|}{ Six days of storage } \\
\hline $0 \%$ NO & $32.305 \pm 0.007$ & $9.623 \pm 0.093$ & $6.574 \pm 0.046$ \\
\hline $0.5 \%$ AFNO & $35.450 \pm 0.563$ & $16.478 \pm 0.259$ & $7.538 \pm 0.285$ \\
\hline $1.0 \%$ AFNO & $34.755 \pm 0.133$ & $12.917 \pm 0.054$ & $7.992 \pm 0.081$ \\
\hline 1.5 AFNO & $34.435 \pm 0.219$ & $15.565 \pm 0.054$ & $6.866 \pm 0.036$ \\
\hline \multicolumn{4}{|c|}{ Ten days of storage } \\
\hline $0 \%$ NO & $31.093+0.049$ & $8.909 \pm 0.036$ & $6.514 \pm 0.058$ \\
\hline $0.5 \%$ AFNO & $34.407 \pm 0.435$ & $16.413 \pm 0.140$ & $6.659 \pm 0.149$ \\
\hline $1.0 \% \mathrm{AFNO}$ & $34.709 \pm 0.099$ & $14.192 \pm 0.037$ & $9.168 \pm 0.021$ \\
\hline 1.5 AFNO & $33.780 \pm 0.220$ & $15.483 \pm 0.100$ & $8.821 \pm 0.084$ \\
\hline
\end{tabular}

Changes in luminosity $\left(\mathrm{L}^{*}\right)$ values obtained upon covering the meat with AFNO over time are shown in Table 1. It, reveals that the $\mathrm{L}^{*}$ value in the loins covered with AFNO has no significant changes. The samples covered with CF decreased the value of $\mathrm{L}^{*}$ with significant changes $(\mathrm{p}<0.05)$ during storage time. This behavior is attributed to the loin samples affected by the loss of moisture, which is translated into lower luminosity. Similar results were reported by Zakaria et al., (2015), who evaluated the effect of the nutmeg extract at different concentrations on the luminosity of raw meat during storage.

The loin samples showed significant differences ( $p<0.05)$, for the $a^{*}$ coordinate, through the nine storage days against loins covered with the CF.
The results obtained agree with Zakaria et al., (2015) who evaluated the effect of the nutmeg extract at different concentrations on the color of raw meat during storage, observing that the different concentrations of nutmeg extract maintained the $a^{*}$ value over time, compared with the control sample. In the same way with Antoniewski et al., (2007) who obtained hight values of $a^{*}$ with increased storage time of the meat, using a gelatin coating. Hence, the AFNO influences on the maintenance of the red tones of the meat as storage time increases. Velasco and Williams (2011) reported that natural antioxidants can delay the loss of meat color extending the red color $\left(\mathrm{a}^{*}\right)$ and delaying the formation of metamyoglobin that gives meat an unattractive brownish color. 
For the $b^{*}$ coordinate no significant differences were observed for the samples covered with AFNO and CF during the storage days. All the samples showed a slight increase in $b^{*}$ values.

The peroxide values reported for all the loin samples had continuous increase during storage time, as noted in Figure 3, and indicate the formation of primary products of lipid oxidation (Yanishlieva and Marinova, 2001).

During storage time, a significant increase $(\mathrm{p}<0.05)$ of peroxides was observed in the samples covered with the CF when comparing these with the samples covered with AFNO. This result confirms that the oxygen barrier properties of the films with NO are higher than the films without adding NO during storage time.
The previous results agree with the studies by Tanabe et al., (2002) who compared antioxidant activities of 22 herbs and culinary species used commonly in lipid oxidation of pork meat. In this case, lipid oxidation was inhibited in the order by nutmeg, caraway, dill, and fennel extracts. The results obtained for the antioxidant activity in the loins were below $10 \mathrm{mEq}$ of oxygen $/ \mathrm{kg}$ of fat), complying with the values established in Resolution 2154/2012.

One of the most-used methodologies to evaluate the degree of meat decomposition is the determination of the TVB-N, which is a key freshness index. Figure 4 displays the results obtained for the TVB-N of the bovine loin samples covered with AFNO and stored at $4^{\circ} \mathrm{C}$ during 1,3 , 6 , and 10 days.

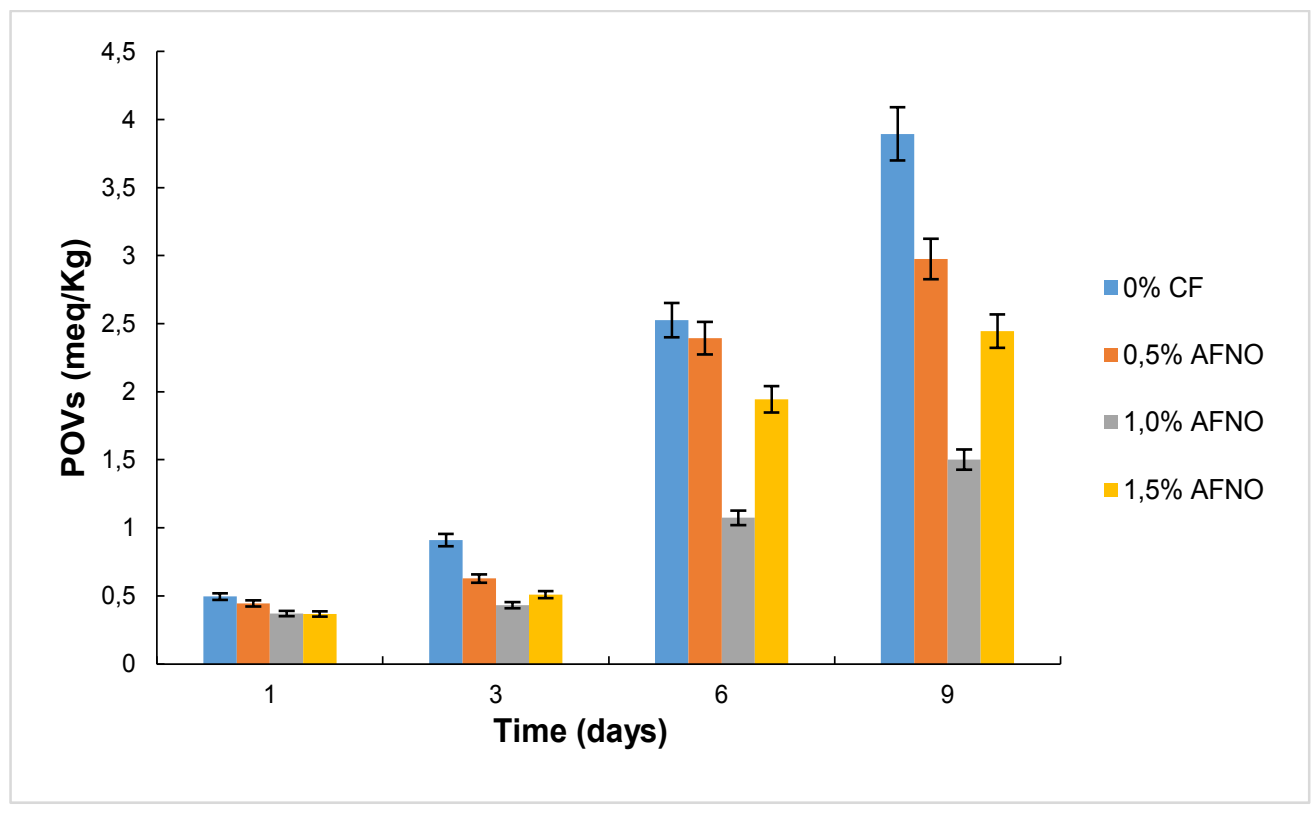

$\mathrm{CF}=$ control film; AFNO = Active film with nutmeg oleoresin.

Figure 3. Peroxide values (POVs) in bovine loin samples during storage time. 


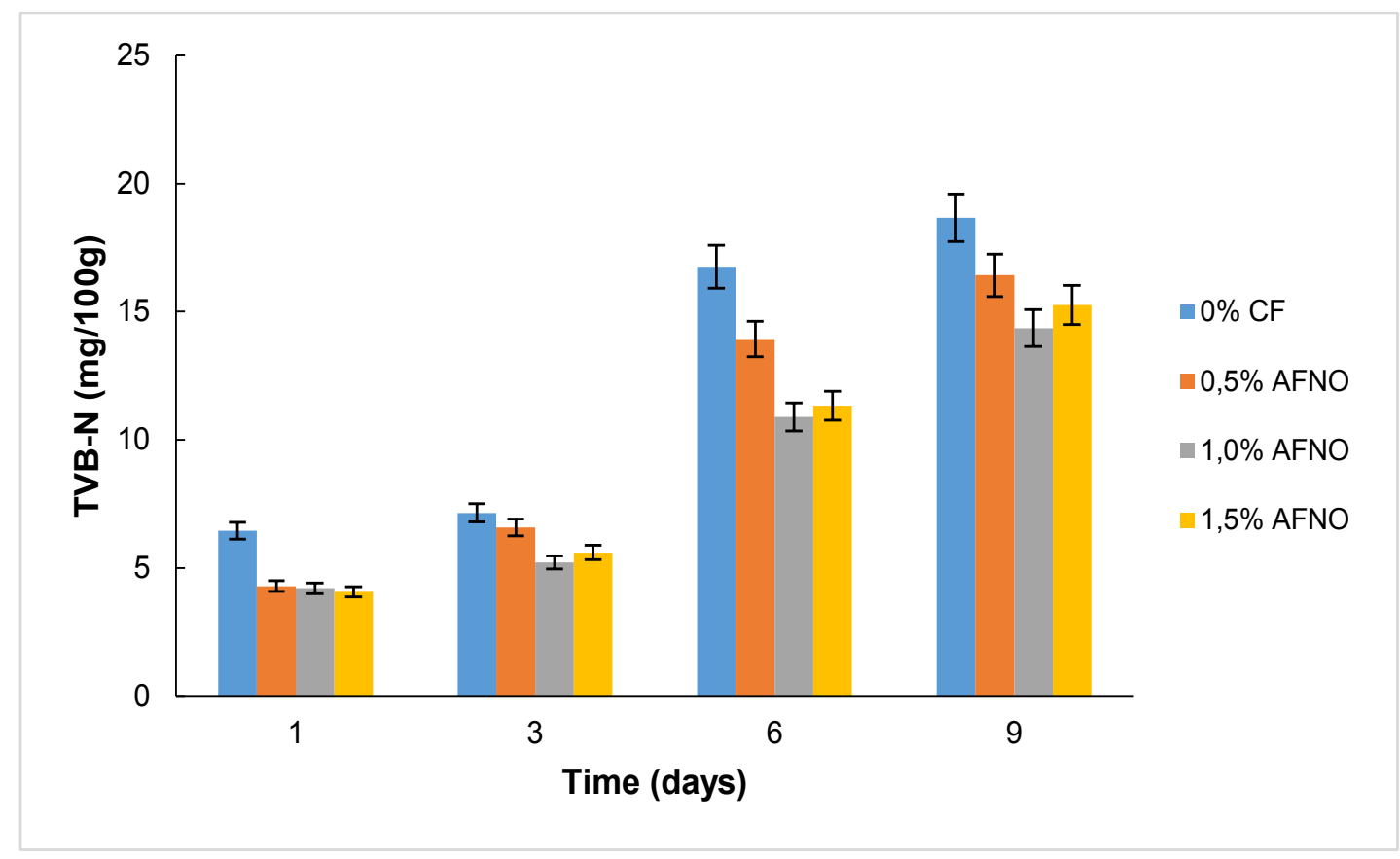

$\mathrm{CF}=$ control film; AFNO = Active film with nutmeg oleoresin

Figure 4. Values of total volatile basic nitrogen (TVB-N) in bovine loin samples during storage time.

The samples covered with AFNO had significant TBV-N differences $(\mathrm{p}<0.05)$ when compared with the samples covered with the CF. The results indicate that the TBV-N values tend to increase with storage time. These were lower than the samples covered with the CF. This behavior indicates the inhibitory effect of the AFNO against secondary oxidation, that is, the delay in releasing nitrogenous substances because of the superior oxygen barrier properties in films with added NO. These results agree with Gómez et al., (2010), who demonstrated that the gelatin and chitosan film with incorporation of nutmeg essential oil was able to reduce the TVB-N value in fish meat during refrigerated storage. The TVB-N values below $20 \mathrm{mg} N / 100 \mathrm{~g}$ indicate that the loins are acceptable for human consumption (Decree 29210 MAG MEIC; Senasa, 2003).

The microbiological analysis of the loin samples covered with the films obtained counts of
Staphylococcus aureus positive coagulase and sulfite-reducing Clostridium spore count $<100$ UFC/g and absence of Salmonella during storage time. Likewise, the Escherichia coli count evidenced antimicrobial activity in all the loin samples covered with AFNO and lower total coliform counts than the samples covered with CF. The results obtained are attributed to the antimicrobial activity associated with the nutmeg oleoresin (Narasimhan and Dhake, 2006) present in the formulation of the active films. The values obtained comply with that established by the technical norms for the microbiological analysis of meat in Colombia.

\section{CONCLUSIONS}

The bovine loins covered with AFNO had a decreased $\mathrm{pH}$, humidity percentage, peroxide values (POVs) and TVB-N values, conserving the red tones of the meat as storage time increased and 
complied with the microbiological requirements established by the Colombian Technical Norms. Hence, the AFNO could be used to prolong the shelf life of bovine loins during the stages of storage and commercialization, enhancing the Colombian meat chain.

\section{ACKNOWLEDGMENTS}

The authors thank the Colombian Administrative Department of Science, Technology, and Innovation (COLCIENCIAS) for funding the project "Intelligent and active biodegradable packages for conservation of bovine loins (Longissimus dorsi)" 111366945140 and the Interdisciplinary Sciences Institute at Universidad del Quindío for the support in developing this research.

Conflict of interest: The authors declare that there is no conflict of interest.

\section{BIBLIOGRAPHIC REFERENCES}

Antoniewski, N. \& Barringer S. (2010. Meat Shelf-life and Extension using Collagen/Gelatin Coatings: A Review. Critical Reviews in Food Science and Nutrition. 50(7): 644-653. doi: http://dx.doi. org/10.1080/10408390802606691.

Antoniewski, M., Barringer, S., Knipe, L. \& Zerby, H. (2007). The effect of a gelatin coating on the shelf-life of fresh meat. Journal of Food Science. 72(6): 382-387. doi: http://dx.doi.org/10.1111 /j.1750-3841.2007.00430.

Botta, R., Lauder, T. \& Jewer, A. (1984). Effect of methodology on total volatile basic nitrogen (TVB-N) determination as an index of quality of fresh Atlantic cod (Gadus morhua). Journal of Food Science. 469(3): 734-736. doi: http://dx.doi. org/10.1111/j.1365-2621.1984.tb13197.

CIE - International commission on illumination. (1976). Colorimetry: official recommendation of the international commission on illumination publication CIE No (E 1.31). Paris, France: Bureau Central de la CIE.
FAO - Organización de las Naciones Unidas para la Alimentación y la Agricultura. (2014). El estado de la inseguridad alimentaria en el mundo. Recuperada de http://www.fao.org/publications/ sofi/2014/es.

Figueroa-López, K., García-Salcedo, A., Torres-Vargas, 0. \& Ariza-Calderon, H. (2016a). Efecto de PVA y pimienta negra en las propiedades estructurales de películas de gelatina. Agronomía Colombiana. 31(1): 156-160.

Figueroa,K.,Andrade,M.\&Torres,0.(2016b).Evaluación de la actividad antimicrobiana de oleorresinas en el desarrollo de películas biocompuestas. Agronomía Colombiana. 34(1): 223-226. doi: http://dx.doi. org/10.15446/agron.colomb.v34n1supl.58218.

Gómez, J., López, A., López, M., Gómez, M. \& Montero, P. (2010). Biodegradable gelatin chitosan films incorporated with essential oils as antimicrobial agents for fish preservation. Food Microbiology. 27(7): 889-896. doi: http://dx.doi.org/10.1016/j. fm.2010.05.012.

HORWITZ, W. (2005). Official methods of Analysis of AOAC International. Recovered from https:// www.researchgate.net/publication/292783651_ A0AC_2005.

ICONTEC, Instituto Colombiano de Normas Técnicas y de Certificación. (2007). Microbiología de alimentos y alimentos para animales. Método horizontal para el recuento de estafilococos coagulasa positiva (Staphylococcus aureus y otras especies). Primera Actualización. Bogotá: (NTC 4779). 10p.

ICONTEC, Instituto Colombiano de Normas Técnicas y de Certificación. (2000). Microbiología de alimentos y alimentos para animales. Método horizontal para el recuento de clostridium sulfito reductor e identificación de clostridium perfringens - técnicas de recuento de colonias. Bogotá: (NTC 4834). 6p.

ICONTEC - Instituto Colombiano de Normas Técnicas y de Certificación. (2007). Microbiología de alimentos y alimentos para animales. Método horizontal para la detección de salmonella SPP. Primera Actualización. Bogotá: (NTC 4574). 9p.

ICONTEC - Instituto Colombiano de Normas Técnicas y de Certificación. (2007). Microbiología de alimentos y de alimentos para animales. Método horizontal 
para el recuento de Coliformes o Eschericchia coli o ambos. Técnica de colonias utilizando medios fluorogénicos o cromogénicos. Primera Actualización. Bogotá: (NTC 4458). 10p.

ISO R-1442. (1997). Meat and meat products Determination of moisture content (Reference method). Recovered from https://www.iso.org/ standard/6037.html.

Lorenzo, J., Batlle, R. \& Gómez, M. (2014). Extension of the shelf life of foal meat with two antioxidant active packaging systems. Food Science and Technology. 59(1): 181-188. doi: http://dx.doi.org/10.1016/j. lwt.2014.04.061.

Ministerio de Salud y de Protección Social. (2012). Resolución 2154. Reglamento técnico sobre los requisitos que deben cumplir aceites o grasas de origen animal o vegetal. Bogotá D.C. Diario Oficial No. 48.516 de 8 de agosto de 2012. Recuperada de https://www.minsalud.gov.co/sites/rid/Lists/ BibliotecaDigital/RIDE/DE/DIJ/resolucion-2154de-2012.pdf

Mancini, A. \&, Hunt, C. (2005). Current research in meat colour. Meat science. 71(1): 100-121. doi:10.1016/j. meatsci.2005.03.003.

Narasimhan, A., \& Dhake, J. (2006). Antibacterial principles from Myristica fragrans seeds. Journal of Medicinal Food. 9(3): 395-399. doi: http://dx.doi. org/10.1089/jmf.2006.9.395.

Peelman, N., Ragaert, R., De Meulenaer, B., Adons, D., Peeters, R., Cardon, L., Impe, F. \& Devlieghere, F. (2013). Application of bioplastics for food packaging. Trends in Food Science \& Technology. 32(2): 128-141. doi: http://dx.doi.org/10.1016/j. tifs.2013.06.003.

Sánchez, I., García, B., Santos, E., Reyes, A., Barboza, E. \& Regalado, C. (2014). Antimicrobial edible films and coatings for meat and meat products preservation. The Scientific World Journal. 1-18p. doi: http:// dx.doi.org/10.1155/2014/248935

SENASA. Servicio Nacional de Sanidad y Calidad Agroalimentaria. (2003). Decreto 29210 MAG MEIC. 2003. Reglamento técnico límites máximos permitidos para residuos tóxicos y recuentos microbiológicos para los productos alimenticios. Recuperada de faolex.fao.org/docs/texts/cos78194.doc.
Šojić, B., Tomović, V., Kocić-Tanackov, S., Škaljac, S., Ikonić, P., Džinić, N., Živkovićc, N., Jokanovića, M., Tasićb, T. \& Kravić, S. (2015). Effect of nutmeg (Myristica fragrans) essential oil on the oxidative and microbial stability of cooked sausage during refrigerated storage. Food Control. 54(1): 282-286. doi: http://dx.doi.org/10.1016/j.foodcont.2015.02.007.

Tanabe, H., Yoshida, M. \& Tomita, N. (2002). Comparison of the antioxidant activities of 22 commonly used culinary herbs and spices on the lipid oxidation of pork meat. Animal Science Journal. 73(5): 389-393. doi: http://dx.doi.org/10.1046 /j.1344-3941.2002.00054.

Umaraw, P. \& Verma, A. (2017). Comprehensive review on application of edible film on meat and meat products: An eco-friendly approach. Critical Reviews in Food Science and Nutrition. 57(6): 12701279. doi: http://dx.doi.org/10.1080/10408398.2 014.986563.

Velasco, V. \& Williams, P. (2011). Improving meat quality through natural antioxidants. Chilean journal of agricultural research. 71(2): 313-322.

Wei, R., Wang, P., Han, M., Chen, T., Xu, X. \& Zhou, G. (2017). Effect of freezing on electrical properties and quality of thawed chicken breast meat. AsianAustralasian journal of animal sciences. 30(4): 569575. doi: http://dx.doi.org/10.573/ajas.16.0435.

Yanishlieva, V. \& Marinova, M. (2001). Stabilisation of edible oils with natural antioxidants. European Journal of Lipid Science and Technology. 103(11): 752-767 doi: http://dx.doi.org/10.1002/14389312(200111)103.

Zakaria, M., Abas, F. \& Rukayadi, Y. (2015). Effects of Myristica fragrans Houtt. (Nutmeg) extract on chemical characteristic of raw beef during frozen storage. International Food Research Journal. 22(3): 902-909.

Zaritzky, N. (2012). Physical-Chemical Principles in Freezing. In: Da-Wen Sun Handbook of frozen food processing and packaging. $2^{\text {nd }}$ edition. London: CRC Press. 3 - 38 p.

Zhang, W.; Xiao, S. \& Ahn, D. (2013). Protein oxidation: basic principles and implications for meat quality. Critical Reviews in Food Science and Nutrition. 53(11): 1191-1201. doi: http://dx.doi.org/10.1080 /10408398.2011.577540. 